\title{
REMITTANCE AND ECONOMIC GROWTH IN NIGERIA
}

\author{
Adligun A.O and Ologunwa O.P \\ Department of Economics, School of Management Technology, Federal University of \\ Technology, Akure, Nigeria. \\ Olaabiodun24@yahoo.com. 08036436473 \\ ddesykay@yahoo.com. 08034098155
}

\section{ABSTRACT}

This study examined remittances in Nigeria and its impact on economic growth between 1980 and 2015 the objective of the study is to look at the correlation between remittance and macroeconomic variables, examine the trend and pattern of remittance in Nigeria using secondary data with time series for the period, the study finds out that workers remit money to finance consumption and investments of their relations which has impacted on the well-being of the recipients, though the impact on economic growth is diverse and so require investigation. The result also shows that remittance remains positive sources of economic growth and can help the poor finance some of their consumption and investment expenditure. Remittance is significant but the magnitude of impact on economic growth and development remain small the study recommended that recipients of remittance should spend more on investment than consumption to impact on the economy.

Keywords; remittance, economic growth, compensatory windfall and institutions

\section{INTRODUCTION}

Remittances are transfers from international migrants to family members in their country of origin. It represents one of the sources of financial flows to developing countries. Remittance is different from other external capital inflow like foreign direct investment, foreign loans and aids due to its stable nature Kapur (2006). Remittance can affect economic growth and development through micro and macroeconomics activities. The drive for encouraging increased workers remittance is to promote economic growth and development. The potential channels of the positive effects of remittance inflows on growth and development prospects of developing economies include how these remittance impact on domestic investment, balance of payment, ease domestic credit constraints, exports, diversification of economic activities, levels of employment and wages, human capital development and technological progress. Barajas (2009) pointed out three channels through which remittances could affect economic growth and development, using growth accounting framework. One, by directly financing an increase in capital accumulation relative to what would have been observed if the recipient economics had been forced to rely only on domestic sources of income to finance investment. Two, by Labour 
inputs through Labour force participation and third, may affect total factor productivity (TFP) growth through effects on the efficiency of domestic investment as well as the size of domestic productive sectors that generate dynamic production externalities.

According to World Bank estimates (Migration and Development Brief, 2016), remittances to developing countries grew marginally in 2015 , as weak oil prices and other factors strained the earnings of international migrants and their ability to send money home to their families. Remittances to developing countries amounted to $\$ 430$ billion in 2014 and to $\$ 431.6$ billion in 2015.They have become the second largest source of external finance for developing countries after foreign direct investment (FDI) and represent about twice the amount of official aid received (Aggarwal, Demirgüc-Kunt, \& Martinez Peria, 2011). However, for many remittancereceiving developing economies, remittance flows exceed foreign direct investment, portfolio flows from financial markets, and official development assistance. Officially recorded remittances are generally underestimated (Reinke,2007).

This is equally applicable to Nigeria as one of the developing countries which has benefited immensely from foreign financial inflows. Between 1960s and 70s most flows into Nigeria were directed to governments in the form of overseas development assistance (ODA) or to the private sector through the banking system. This situation changed in the 1980s and Foreign Portfolio Investment (FPI). Prior to 1986, Nigeria did not record any figure on portfolio investment (outflow or inflow) in her Balance of Payment (BOP) accounts. For decades, the FDI dominated the financial inflows to Nigeria but recently, workers' remittances have taken the center-stage. As observed by Barajas (2009), workers remittance are transfer from international migrants to family members in their country of origin represent one of the largest sources of financial flows to developing countries. The increase in the other external flows, such as foreign direct investment and portfolio investment could be attributed to the relatively stable political environment as well as the Federal drive for foreign investment

Meanwhile, the nature of migration phenomenon in Nigeria took two different epochs after her independence in 1960. Post-independence migration periods took the form of Nigerians moving abroad to acquire western education due to apparent dearth of manpower at home. During this period, the ultimate goal was to acquire education and relevant skill gaps that would fill the job spaces, whereas the drive to remit money home was very remote. Thereafter, especially from the early 1980s migration took a different dimension. Migrants left for different reasons and could be mostly grouped as economic migrants. The MDG (2005) claimed that remittance tend to act as financial catalylist to close the gap of financial requirement of USD273 billion, expected to rise to USD335billion in 2015 for poverty to reduce by half in the year. This is because the inflow is consistent and tends to increase with rising number of migrants. Second, it plays a crucial role in the private sector, economic growth and job creation through increase in consumption, investment and relatively favorable income redistribution. Ogwumike and Olubiyi, (2009).

Some school of thought believed that workers' remittances have positive effect on the economy while some say it does not have any effect on the economy. Remittances increase the foreign 
exchange earnings of the countries as well as the income of the receivers. The sheer volume of remittances of selected countries indicates that remittance do have a positive effect on the receiving households in terms of improved standard of living, which triggers a positive effect for the local economy due to increased consumption and investments. However there is no consensus to what degree remittances contribute to economic growth and employment creation. Most studies reveal that up to 80 percent of remittances are used for basic household's consumption and 5-10 percent is used to invest in human capital such as education, health and better nutrition. Also important is that remittance are invested in land, housing and livestock, often seen as (future) assets for the emigrants, smaller proportions of remittance are spent on socio-cultural events for loan repayments, savings and generally only little is invested in employment and income generating activities other than agriculture and livestock. Sanders (2003) and Suro (2003)

One paradox in the face of growth enhancing claims of remittances is that, given the large number of Nigerians abroad, remitting billions of US dollars, if remittance were not as large as it is now, would Nigeria growth trend have risen or fallen? If the current growth time path of remittance continues, what will be the state of the economy in the next 30 years? These debates become more curious given that the growth rate of the country before the surge in remittances was not better than the period of sizable remittances. It appears that very few country-specific studies address the development effect of remittances in Nigeria. Most available studies focus on the effect of remittances on development for a panel of developing countries or sub Saharan Africa (SSA). Observably, there is a need to clarify the relationship between remittances and economic development.

This paper seeks to address this need by using country specific analysis and appealing to more robust methodology to address possible problems. Giving the foregoing, the questions are what are the macroeconomic determinants of remittances in Nigeria? What are the relationship between remittances and its determinants? Should there be deliberate policies to encourage or discourage the issue of remittances? The need for this paper is to show the correlations between remittances and macroeconomic variables, in particular gross domestic product and growth variables like investment, interest rate, exchange rate and to examine the current trend and pattern of remittances in Nigeria. The paper will look at remittance and its implication on Economic growth in Nigeria from 1980 to 2015.

\section{LITERATURE REVIEW}

Remittance is the inflow of money that result from migration, migration in this study is the voluntary movement of person from a country of origin to seek a more prosperous environment and or to ensure the safety of life. When migration is documented it is termed regular, the reverse is termed irregular migration. Human trafficking is not migration because people were forced to move against their will. Fundamentally, the theory of migration takes into cognizance the various labour market opportunities available to labour in developing countries. The theoretical underpinning is those individuals who choose employments that maximize their expected gains 
from migration. The labour-force, both actual and potential, compare expected incomes for a given horizon in the labour receiving country with the domestic incomes and migrate if the former exceeds the latter Todaro (1969). One of the most favorable outcomes of migration is remittances. According to World development Indicator (WDI), Remittances involves personal transfer which includes all current transfer in cash or in kind between resident and non- resident individuals, independent of the sources of income of the receiver. Other believed it is the transfer of money by a foreign worker to an individual in his or her home country.

The International Labour Organization ILO (2001) defined remittance as the portion of international migrants workers' earnings sent back from the country of employment to the country of origin. Also, Levitt's (1996) stated that it is ideas, practices, identities and social capital that flow as social remittances. Ahlburg (1991) discusses remittance in a broader perspective as a reflection of monetary dimension in the complex web of linkages that exist between migrant Diasporas and their home countries. Remittances can be sub-classified into financial remittances, social remittances and remittances-in-kind. Financial remittances are the inflow of cash and financial products. Cash are sent formally through the banks and network of International Monetary Transfer Organizations (MTOs) and also conveyed through informal channels. Financial remittances could also be in the form of Diaspora bond receipts that are designed by the home countries to attract funds from the Diasporas. The Diaspora provides social remittances to their local communities in the area of health, education as well as the building of infrastructure through donations of funds. Social remittances also include the values and norms on which social capital is based for example social and political leaders can sometimes harness the status they acquire in the host country to advance their cause in the homeland.

They also include values amount how organizations should work, incorporating ideas about good government, good churches and about how politicians and clergy should behave. These includes again how individuals delegate household tasks, the kinds of religious rituals they engage in and how much they participate in political and civic groups. Social remittances are passed systematically and intentionally. A social remittance occurs when migrants speak directly to a family member about a different kind of politics and encourage them to pursue reforms. In cases such as these, ideas are communicated intentionally to a specific recipient or group. People know when and why they changed their mind about something or began to act in a different way. Remittance-in-kind are goods that are sent from abroad to countries of origin. This can take the form of clothing items, medicines, toiletries, books, electronics equipment and in certain cases automobiles.

Olowa (2013) used household survey to analyze the impact of both domestic and foreign remittances on poverty in rural Nigeria and finds out that poverty is reduced more than when domestic, as opposed to foreign remittance are included in household income. They believed that remittances can be poverty reducing but the extent to which remittance affect poverty and income inequality has not been adequately documented in Nigeria. Iheke (2012) was of the opinion that remittance inflow has been on the increase over the past two decades. Also 
remittances, per capita income, investment and time were the positive and significant factors influencing output while consumer price index significantly influenced output negatively. Orozo (2005) in his view, believed that the wave of money reported the world over, has particularly resonated in Latin America and the Caribbean and that workers' remittances sent from the USD \$45billion in 2004 and are estimated to grow to $\$ 51$ billion or more in 2005 . He addresses remittances as part of a broader process of integration in the global economy through what he term "the five Ts"; tourism, transportation, telecommunications, transfer and trade.

Oduh and Urama (2012) said international remittance has changed the landscape of international migration from brain drain to brain circulation and provide the developing countries the opportunity to raise alternative sources of consumption and investment financing. They discovered that the simulation result shows that the much touted poverty-reducing effect of remittances is non-growth financing for import-dependent country like Nigeria because of its negative impact on current account balance, despite its positive effects on private consumption and investment. Olubiyi and Kehinde (2015) were of the view that the size and rate of remittances to Nigeria is remarkable, Using choice-theoretical model, real exchange rate impacted negatively on remittances, implying that an expected depreciation of the real exchange rate which signals adverse economic conditions back home dwarfs remittance inflows.

Aggarwal et al. (2011) empirically explore the impact of remittances on financial system development, using a homogenous panel model of 99 developing countries. The authors find evidence that remittances promote financial development by increasing the aggregate level of deposits and credits. Gupta, Pattillo, and Wagh (2009) examine the influence of remittances on financial development on a panel sample of 44 Sub-Saharan African (SSA) countries. They find the same evidence, namely that remittances help to pro-mote financial development. DemirgücKunt, Cordova, Peria, and Woodruff (2011) find evidence that remittances increase banking breadth and depth in Mexico by increasing the number of branches and accounts per capita and deposits. Estimating a homogenous panel data model on annual data from 94 developing economies, Cooray (2012) finds that remittances increase the size of the financial sector in countries with lower government ownership of banks, while they improve financial sector efficiency in countries with higher government ownership of banks. Calderon, Fajnzylber, and Lopez (2008), indicate that remittances can reduce credit demands and "have a dampening effect on the credit markets." Brown (2013) estimates the relationship between remittances and financial development using cross-section panel data. They find that after controlling for per capita GDP, other macroeconomic factors, and the country where the funds originate, remittances do not increase domestic credit to the private sector.

\section{DETERMINANTS OF REMITTANCE}

Understanding the underlying motivation behind remitting is necessary for investigating the economic impact of remittances, for at least two reasons. First, the amount a migrant remits depends on the migrant's underlying reasons to migrate and reasons to remit in the first place. In turn, the size and timing of remittance flows determine their impact on economic activity in the 
home country. Second, the intended purposes of remittance also impact the end uses of these flows. The uses to which recipients put remittances are important determinants of their economic impact on home country Chami (2008). Lucas and Stark (1985) believed that migrants send remittances simply because they care about the well-being of those left behind. This implies that there is a positive relationship between adverse conditions of the family left behind and the amount of remittances sent by the migrant. Altruistic transfer should increase with the migrants' income and his degree of altruism and decrease with the recipient's income and the recipient' degree of altruism, Funkhouser (1995). The altruism motive is the most intuitive and widespread presumption, the earliest studies on remittances Johnson and Whitelaw (1974) already mention altruistic motives for remitting.

Again, remittance may be motivated by self-interested reasons, these self-interested theories of remittances view the family as a business or as a nexus of contracts that enables family members to enter in Pareto-improving exchanges Chami, Fullenkamp and Jahjah (2005). There are many situations of Pareto-improving exchanges involving remittances, the most obvious situation is one where remittances buy various types of services such as taking care of the migrant's assets (land, cattle's) or relatives at home. Lucas and Stark (1985) argue that migrants may have investments that need to be managed, while they are away, so they use family members as members as their trustworthy and well-informed agents. Such motivations generally signal the migrant's intention to return home someday Rapoport and Docquier, (2005). Another way to think of Pareto-improving exchanges is to consider the case where a migrants remits to demonstrate laudable behavior as an investment for the future or with the hope to inherit, HagenZanker and Siegel,(2007). As emphasized by Hoddinott (1994), remitting can make the migrants eligible for inheritance or other resources in the community of origin. If a migrant expects to inherit from relatives, remittance should increase with the recipient households' income and other assets. As Pozo (2005) observed in Latin America, Altruism is an important motive underlying the transfer of monies from immigrants to families, but in many cases, the migrants is also insuring for the raining day.

\section{METHODOLOGY}

Multiple Regression analysis is used to find the relationship between the variables; economic growth is treated as a dependent variable remittances and exchange rate, interest rate as independent variables

\section{GDP $=\alpha_{0}+\alpha_{1}$ Rem $+\alpha_{2}$ Ivst $+\alpha_{3}$ Exr $+\alpha_{4}$ Int + V}

GDP stands for Gross Domestic Product, Rem stands for Remittances, Ivst stands for Investment, Exr equally stands for exchange rate, Int. stands for Interest rate. Also, $\alpha_{0}$ is the constant term and $\boldsymbol{\alpha}_{1}, \boldsymbol{\alpha}_{2}, \boldsymbol{\alpha}_{3} \& \boldsymbol{\alpha}_{4}$ are coefficients to be estimated and $V$ is the error term with properties (normally distributed). The empirical model suggests that economic growth depends on previous level of per capita income, the ratio of remittances of DGP and a set of control variables. The primary focus of the empirical model is to assess the nature and magnitude of the estimate of remittances and its effect on GDP, if the marginal impact on growth is positive, one 
will find a positive coefficient $\alpha_{1}$. First, the effect of remittances on economic growth will be estimated using ordinary least square method (OLS), Co-integration analysis will be used but the stationarity test will be carried out before then in this model, it is expected that remittances, investment, exchange rate will have a positive impact on economy growth while interest rate will have a negative effect on the economy.

\section{DATA ANALYSIS AND RESULT}

This section contains the result of the correlation analysis, stationarity test, cointegration test and OLS regression.

Table 1; Correlation Result

\begin{tabular}{|l|l|l|l|l|l|}
\hline & REMIT & INV & GDPPC & EXR & INTR \\
\hline REMIT & 1.000000 & 0.655619 & -0.492354 & -0.403732 & -0.608747 \\
\hline INV & 0.655619 & 1.000000 & 0.033333 & 0.117053 & -0.221840 \\
\hline GDPPC & -0.492354 & 0.033333 & 1.000000 & 0.885904 & 0.565544 \\
\hline EXR & -0.403732 & 0.117053 & 0.885904 & 1.000000 & 0.542195 \\
\hline INTR & -0.608747 & -0.221840 & 0.565544 & 0.542195 & 1.000000 \\
\hline
\end{tabular}

There is an evidence of positive and high correlation between remittances and domestic investment in Nigeria which implies that remittance tends to increase the level of investment in Nigeria but per capital income, interest rate and exchange rate shows negative correlation, which means the rate at which remittance impact on them are quite insignificant Although, it is expected that remittances and GDP per capita will exhibit positive correlation but the reverse is the case. However, as it correlates positively with investment, it is expected that remittance will have an impact on the level of income of the recipients. Investment and GDP per capita and exchange rate show positive relationship with each other but negative relationship with interest rate, that means investment, GDP per capita and exchange rate impact on each other's positively. GDP per capita which measures the welfare of the recipients correlates high and positive impact on both exchange rate and interest rate. Exchange rate shows positive relationship with interest rate, the implication of these is that as remittances flow into the country, it usually affects the domestic macroeconomic variables as well thereby exerting multi-dimensional impacts on the economy

\section{STATIONARITY TEST}

In other to ensure that non-stationarity variables are not used to estimates the specified regression model, the stationarity property of the series are examined as presented in table II 
Available online on http://www.rspublication.com/ijrm/ijrm_index.htm Issue 7, Vol. 6 (October-November 2017)

Table 2: Stationarity Test with ADF

\begin{tabular}{|l|l|l|l|l|}
\hline Variable & Level & First Difference & $\begin{array}{l}\text { Second } \\
\text { Difference }\end{array}$ & REMARK \\
\hline REMITTANCE & $-3.742829 *$ & $-2.246983 * *$ & $-3.648363 * *$ & $1(0)(1)(2)$ \\
\hline INVESTMENT & $-3.783283 *$ & $-3.059811 * *$ & $-5.892125 * * * *$ & $1(0)(1)(2)$ \\
\hline GDP per capita & $8.738571 * * * *$ & $-20.41303 * * * *$ & $-19.32745 * * *$ & $1(0)(1)(2)$ \\
\hline EXCH. RATE & & $-5.217246 * * * *$ & $-9.082633 * * * *$ & $1(1)(2)$ \\
\hline INTEREST RATE & & $-5.667800 * * * *$ & $-6.666330 * * *$ & $1(1) 2$ \\
\hline
\end{tabular}

$*,{ }^{*},{ }^{*} * *, * * * *$ denote that the variables are significant at $1 \%, 5 \%, 10 \%$ and at all levels

The unit root test shows that all variables except for exchange rate and interest rate are stationary at first and second order difference, but since all variables are stationary at second order difference, the variables are good and amendable for further estimation.

Table 3: Johansen Co-integration Test

\begin{tabular}{|c|c|c|c|c|}
\hline \multicolumn{4}{|c|}{ Unrestricted Cointegration Rank Test (Trace) } & \\
\hline & & & & \\
\hline Hypothesized & & Trace & 0.05 & \\
\hline No. of CE(s) & Eigenvalue & Statistic & Critical Value & Prob.** \\
\hline None* & 0.812632 & 130.9745 & 69.81889 & 0.0000 \\
\hline At most $1 *$ & 0.638540 & 80.73403 & 47.85613 & 0.0000 \\
\hline At most $2 *$ & 0.582788 & 50.20591 & 29.79707 & 0.0001 \\
\hline At most $3 *$ & 0.451469 & 23.98110 & 15.49471 & 0.0021 \\
\hline At most $4 *$ & 0.180334 & 5.965746 & 3.841466 & 0.0146 \\
\hline \multicolumn{5}{|c|}{ Trace test indicates 5 cointegrating eqn (s) at the 0.05 level } \\
\hline \multicolumn{5}{|c|}{$*$ denotes rejection of the hypothesis at the 0.05 level } \\
\hline \multicolumn{5}{|c|}{ **Mackinnon-Haug-Michelis (1999) p-values } \\
\hline \multicolumn{5}{|c|}{ Unrestricted Cointegration Rank Test (Maximum Eigenvalue) } \\
\hline & & & & \\
\hline Hypothesized & & Max-Eigen & 0.05 & \\
\hline No. of CE (s) & Eigenvalue & Statistic & Critical Value & Prob.** \\
\hline None* & 0.812632 & 50.24049 & 33.87687 & 0.0003 \\
\hline At most $1 *$ & 0.638540 & 30.52812 & 27.58434 & 0.0203 \\
\hline At most $2 *$ & 0.582788 & 26.22481 & 21.13162 & 0.0088 \\
\hline At most $3 *$ & 0.451469 & 18.01535 & 14.26460 & 0.0122 \\
\hline At most $4 *$ & 0.180334 & 5.965746 & 3.841466 & 0.0146 \\
\hline \multicolumn{5}{|c|}{ Max-eigenvalue test indicates 5 cointegrating eqn(s) at the 0.05 level } \\
\hline \multicolumn{5}{|c|}{$*$ denotes rejection of the hypothesis at the 0.05 level } \\
\hline \multicolumn{5}{|c|}{ **Mackinnon-Haug-Michelis (1999) p- values } \\
\hline & & & & \\
\hline
\end{tabular}


It can be observed from the co-integration test that both the trace test statistics and the maximum Eigen value test indicate five (5) co-integrating equations at $5 \%$ level of significance. Therefore, based on these evidences, it is safe to reject the null hypothesis of no co-integrating vectors or no significant long run relationship between the variables, especially remittances and economic growth and accept that there is a presence of co-integrating vector among the time series variables of the model or that there is long run relationship existing among the variables that have been included in the model specification.

\section{OLS Regression Result for the Impacts of Remittances on Economic Growth}

In order to test for the impacts of remittances on economic growth in Nigeria, an Ordinary least square approach is adopted and the result is presented below.

Table 4; Remittance effects on GDP

\begin{tabular}{|c|c|c|c|c|}
\hline \multicolumn{4}{|c|}{ Dependent Variable; LOG (GDPPC) } & \\
\hline \multicolumn{4}{|c|}{ Method Least Squares } & \\
\hline \multicolumn{5}{|c|}{ Date: $06 / 16 / 15$} \\
\hline \multicolumn{5}{|c|}{ Sample: 1980-2015 } \\
\hline \multicolumn{5}{|c|}{ Included observations: 35} \\
\hline Variable & Coefficient & Std. Error & t--Statistics & Prob. \\
\hline $\mathrm{C}$ & 10.63432 & 1.482830 & 7.171639 & 0.0000 \\
\hline LOG (REMIT) & 0.223047 & 0.110090 & 2.026037 & 0.0524 \\
\hline LOG (INV) & 1.218394 & 0.478360 & -2.547023 & 0.0166 \\
\hline EXR & 0.375271 & 0.080131 & 4.4683236 & 0.0001 \\
\hline INTR & -0.189109 & 0.230717 & -0.819660 & 0.4196 \\
\hline R-squared & 0.509168 & \multirow{6}{*}{\multicolumn{2}{|c|}{$\begin{array}{l}\text { Mean dependent var } \\
\text { S.D. dependent var. } \\
\text { Akaike info criterion } \\
\text { Schwarz criterion } \\
\text { Hannan-Quinn criter. } \\
\text { Durbin-Watson stat }\end{array}$}} & 12,71904 \\
\hline Adjusted R-square & 0.456579 & & & 0.940665 \\
\hline S.E. of regression & 0.693431 & & & 2.222138 \\
\hline Sum squared resid & 13.46370 & & & 2.405355 \\
\hline Log likelihood & -31.55421 & & & 2.282869 \\
\hline F-statistics & 9.681993 & & & 1.515157 \\
\hline Prob(F-statistic) & 0.000150 & & & \\
\hline
\end{tabular}

The coefficient of the determination of the model shows that the independent variables (remittances, investment, exchange rate and interest rate) impact the total variation in GDP per capital up to a tune of $51 \%$. This implies that the coefficient of the variation indicates good fit and moderate predictive power of the model. The adjusted R-Square result is lower than that of $\mathrm{R}$-square. After adjusting for degree of lost in the confidence interval, R-square adjusted reveals that there joint explanatory powers of included explanatory variables is up to $45.7 \%$. in this case, about $54.3 \%$ of total variation in GDP per capita is accounted for by other factors outside the explanatory power of the variables. In terms of the significant of each of the explanatory 

increase in GDP per capita in the economy. In this case, the welfare of the recipient of such remittances will increase; similarly, a $1 \%$ increase in the level of investment will lead to increase in GDP per capita by about $1.23 \%$. This significant and positive relationship may not be unconnected with the impacts of remittance on the level of investment of the recipients.

Exchange rate showed a positive relationship with GDP in line with remittance of Nigerians in diasporas. Here, appreciation to the domestic currency will lead to about $0.37 \%$ in GDP per capita. The result for interest rate is negative and not significant as a determinant of the level of impacts of remittance on economic growth in Nigeria. Finally it is noteworthy that even though the percentage of the rate of impacts of remittances on economic growth in Nigeria through increase in GDP per capita of the recipients, remittances are viable mechanism through which most of the nationals in Diaspora can contribute to the welfare of their family members, which inadvertently instigate increase in GDP per capita of the recipients, and hence economic growth.

\section{CONCLUSION AND RECOMMENDATIONS}

This study examined remittances in Nigeria and then impact on economic growth from 1980 to 2015.The unit root test shows that all variables, except exchange rate and interest rate are stationary at levels, first and second difference. The co-integration test shows that it is safe to reject the null hypothesis of no co-integrating vectors The trends of the growth path in total inflow of remittances to Nigerians by relatives in diasporas have not been smooth over the years,. Between 1988 and 2004, the trend in total remittances has been sluggish. However, between 2005 and 2006 the trend increases to 101.6 million dollar and later fluctuated till 45.2 million dollar in 2011. From the OLS result, it shows that all the variables are positive except interest rate, the result shows that remittances investment, exchange rate will lead to economic growth while interest rates are contrary. The positive and significant relationship in investment may not be unconnected with the impacts of remittances on the level of the recipients

It is evident that increase in total remittances over the years leads to increase in Gross Domestic Product (GDP) per capita. Remittances are positively related to economic growth and it is statistically significant. Investment, exchange rate on the other hand is positively related while interest rate is negative and not significant as a determinant of the impacts of remittances on economic growth. We then recommend that government should encourage the recipient to channel such funds to the productive sector of the economy, entrepreneurship skills should be encourage among the populace. Recipients of remittances spend more on investment than on consumption. However, the investment component of remittance spending is not strong enough to off-set the negative impact of import demand; thus, raising the fear that growth-financing of remittances inflow is neutralized by high-import dependence of the country. Instructively the benefits of remittances can only be growth-financing if the destination country has a policy of import substitution particularly for consumer goods. 


\section{REFRENCES}

Aggarwal, R., Demirgüc-Kunt, A., \& Martinez Peria, M. S. (2011). Do workers' remit-tances promote financial development? Journal of Development Economics, 96(2),

Ahlburg D.A. (1991), Migration, remittances and the distribution of Income; Evidence from the Pacific Asian . Asian and Pacific Migration Journal, Vol.4, No 1, 1995.

Barajas, A. , Chami,R., Fullenkamp., Gapen, M., \& Montiel,P (2009). Do workers' remittances promote economic growth? (IMF Working Paper No.153) Retrieved from HYPERLINK "http//www.imf.org/pubs/ft/wp/2009/wp09153.pdf" http//www./imf.org/external/pubs/ft/wp/2009/wp09153.pdf

Brown, R. P. C., Carmignani, F., \& Fayad, G. (2013). Migrants' remittances and financial development: Macro- and micro-level evidence of a perverse relationship. The World Economy, 36(5), 636-660.

Calderon, C., Fajnzylber, P., \& Lopez, J. H. (2008). Remittances and growth: the role of Complementary policies. In P. Fajnzylber, \& J. H. Lopez (Eds.), Remittances and development: Lessons from Latin America. Washington, DC: World Bank.

Cooray, A. (2012). Migrant remittances, financial sector development, and the government ownership of banks: Evidence from a group of non-OECD. Journal of International Financial Markets Institutions and Money, 22, 936-957.

Chami,R. ,Hakura, D., \& Montiel,P.(2009). Remittances: An automatic output stabilizer? (IMF Working Paper No. 91) Retrieved from http://www.imf.org/external/pubs/ft/wp/2009/wp/2009/wp0991.pdf

Chami R, Fullenkamp C, Jahjah S (2003), Are Immigrant Remittance Flows a source of Capital for Development? IMF Working Paper No. 03/189.

Demirgüc-Kunt, A., Cordova, E. L., Peria, M., \& Woodruff, C. (2011). Remittances and banking sector breadth and depth: Evidence from Mexico. Journal of Development Economics, 95(2), 229-241

Funkhouser, E. (1995), Remittances from International Migration, The Review of Economics and Statistics, Vol.77, No 1, pp 137

Gupta, S., Pattillo, C., \& Wagh, S. (2009). Effect of remittances on poverty and financial development in Sub-Saharan Africa. World Development, 37(1), 104-115. 
Hagen-Zanker, J. \& Siegel,M (2007). The determination of remittances: A review of the literature (MGSOG Working Paper No.003). Retrieved from HYPERLINK "http://www.merit.unu.edu/publications/mgsog_wppf/2007/wp2007.003.pdf

Hoddinott, J. (1994), a Model of Migration and Remittances as Applied to Western Kenya. Oxford Economic Papers 46(3), 459-476.

Iheke O.R. (2012), the effect of Remittance on the Nigerian Economy, International Journal of Development and Sustainability, Vol.1, No 2 (2012) Pages 614-621.

Kapur, D. (2004) Remittances: The New Development Mantra? G-24 Discussion Paper No. 29, UN Conference on Trade and Development. Geneva: United Nations.

Levitt Steven D. (1996), Evidence from Prison Overcrowding Litigation-Price theory; Quarterly Journal of Economies, Volume III, No 2,(May 1996) 319-351.

Lucas, R.E.B.and Stark O. (1985). "Motivations to Remit; Evidence from Botswana.” Journal of Political Economy, 93, 901-918.

Oduh, M. O. and Urama, N.E. (2012), "Does the End Use of Remittance Matter? A Macro Simulation of the Nigerian Economy; Developing Country Studies, Volume 2, No 10, 2012

Ogwumike, F.O. and Olubiyi, E.A. (2009). Remittances and Economic Development in SubSaharan Africa. Indian Journal of Economics 2009

Olowa, O.W; Awoyemi, T.T; Shittu, M.A; Olowa, O.A.(2013) effects of Remittances on Poverty among Rural Households in Nigeria. European Journal of Sustainable Development. 2, 4. Pp 263-284.

Olubiyi, E. A. and Kehinde, K.O. (2015). Does Exchange Rate Affect Remittances in Nigeria?, The Review of Finance and Banking, Volume 07, Issue 1, 2015, pp 031-045.

Orozco, M. (2005), Remittances in the Latin American and Caribbean Region; A review of its Economic Impact.. Inter-American Dialogue

Pozo, S. and Amuedo-Dorantes, C. (1995). Migration, Remittances, Male and Female Employment Patterns, the American Economic Review 96 (2), 222-226. 
Available online on http://www.rspublication.com/ijrm/ijrm_index.htm Issue 7, Vol. 6 (October-November 2017)

Rapport, H. and Docquier (2005), the Economics of Migrants Remittances IZA Discussion Paper, No. 1531, march 2005.

Reinke, J. (2007). Remittances in the balance of payments framework: Current prob-lems and forthcoming improvements. In Seminar on remittance statistics. Sobiech, I. (2015).

Sanders and Suro (2003), Remittances and Poverty in Kenya

Skeldon, R (2002). Migration and Poverty Asia-Pacific Population Journal, 17(4); 67-82.

The Millennium Development Goals Report (2005) United Nations Report, New York.

Todaro, P. M. (1997) Urbanization, Unemployment, and Migration in Africa: Theory and Policy. Paper Prepared for Reviewing Social and Economic Progress in Africa. Dharam Ghai: Macmillian. Ed

Chami R, Fullenkamp C, Jahjah S (2003). Are Immigrant Remittance Flows a source of Capital for Development? IMF Working Paper No. 03/189.

World Bank (2008a) Migration and Remittances Fact Book 2008, Washington D.C: The World Bank.

World Bank. (2016). Migration and development brief 26. April 2016. 